\title{
Recepção - Teatro da Vertigem: Uma poética do corpo e suas interações sociais
}

Elizabeth Maria Néspoli ${ }^{1}$

\section{Resumo}

Este artigo é uma primeira aproximação à pesquisa de doutorado que tem como objeto de estudo a recepção na cena contemporânea. Tal investigação é realizada por meio de um estudo de caso: o acompanhamento do processo de criação e da atividade receptiva ao espetáculo Bom Retiro, 958 metros, do grupo paulistano Teatro da Vertigem, em temporada até dezembro de 2012. A pesquisa baseia-se em observação participante e fundamenta-se nas teorias da crítica genética e da estética da recepção.

Palavras-chave: Processo de criação, Recepção, Teatro da Vertigem.

\section{Abstract}

This article is a first approach to the Ph.D research, which has as object of study the 'theatre reception'. The research went through a case study concerning to the creation process and reception of Bom Retiro, 958 metros, as staged by Teatro da Vertigem, still running until December, 2012. This work deals with the procedure known as 'participant observation' and is based on Genetic Critical and Reception Aesthetics.

Keywords: Creation process, Reception, Teatro da Vertigem

Acredito que, para qualquer pesquisador, a melhor oportunidade de aprendizado e confrontações está na prática e na experiência viva, onde as ideias podem morrer ou tomar corpo. Ileana Diéguez Caballero. In: Cenários Liminares - Teatralidades, Performances e Política.

\section{Buscando instrumentos para tecer}

O interesse em realizar uma investigação verticalizada sobre a atividade receptiva na cena contemporânea nasceu de minha experiência como jornalista especializada em teatro. Em quinze anos de atuação no suplemento cultural do jornal diário $O$ Estado de S. Paulo, centenas de entrevistas com criadores envolvidos no fenômeno teatral permitiram-me perceber que muitas são as projeções sobre os efeitos que se quer provocar no espectador, porém raras são as pesquisas de campo com prospecção ampla sobre a recepção. ${ }^{2}$ Refiro-me a um campo de tensão específico, um

\footnotetext{
${ }^{1}$ Doutoranda do Programa de Pós-Graduação em Artes Cênicas da Escola de Comunicações e Artes, Universidade de São Paulo, jornalista e crítica teatral.

2 Buscando compartilhar pesquisas nesse campo acompanhei o I Colóquio Internacional da Recepção:
} 
lugar relacional, de interações múltiplas e complexas, que é o território provisório que se instaura quando a obra teatral encontra seu público, quando os procedimentos de criação são compartilhados no tempo e no espaço da apresentação.

Esse 'lugar de relação', entre a criação teatral e sua atualização como experiência pelo receptor, é o objeto de minha pesquisa de doutorado intitulada Teatro da Vertigem: Construção Poética e Recepção. A proposta é que a investigação se dê por meio de um estudo de caso: o acompanhamento da criação, desde os primeiros ensaios, do espetáculo Bom Retiro, 958 metros - que tem o bairro paulistano do Bom Retiro como tema e território - seguido de prospecção da atividade receptiva durante toda a temporada.

Na definição do alemão Wolfgang Iser, um dos teóricos fundadores da estética da recepção, o que chamamos de obra é uma virtualidade, um potencial de efeitos, que só se realiza quando se torna evento atualizado pelo receptor. Iser define o efeito estético como um conjunto de estruturas presentes na obra que ativam processos de realização de sentido (ISER 1996 p. 62). Porém esse teórico reconhece a necessidade heurística de isolar as partes para análise, ainda que alerte para o risco do predomínio desse procedimento, que poderia resultar no desaparecimento do campo de tensão que se instaura no encontro evento-espectador e deve ganhar a primazia do investigador da atividade receptiva (ISER 1996 p. 50-51).

Aceita a premissa de que tal objeto de estudo requer a investigação isolada das partes dessa relação, ainda se pode perguntar sobre a necessidade de acompanhamento do processo de criação. O diretor e teórico italiano Eugenio Barba cunhou o termo "etnocentrismo de espectadores" em crítica aos que realizam suas análises a partir do espetáculo, sem conhecer a lógica do processo de criação (BARBA 1994 p. 68-69). Ponto de vista comentado pelo italiano Marco de Marinis, professor doutor da Universidade de Bolonha, em artigo que defende a renovação da pesquisa em teatro a partir de "uma nova teatratologia pós-semiótica, pluridisciplinar e com caráter experimental" (MARINIS 2010 p. 99). Em concordância com Barba, Marinis afirma que o trabalho em campo é prática indispensável na investigação científica da cena.

Abordagens sobre a Relação Obra de Arte/Espectador, realizado em Salvador, de 3 a 7 de setembro de 2012, no âmbito do Programa de Pós-Graduação em Artes Cênicas da Universidade Federal da Bahia. Participaram doze palestrantes de contribuição reconhecida ao estudo da cena, entre eles a cubana lleana Diéguez Caballero, a colombiana Beatriz Risk, o argentino Jorge Dubatti e a alemã Barbara Pense. Todos abordaram procedimentos de criação da cena contemporânea em articulação com seus efeitos sobre a recepção, por exemplo, teatralidades expandidas pela interação entre cidadãos e artistas. Porém as análises apresentadas foram realizadas sempre sob o ponto de vista do pesquisador. Sem desmerecer a produtividade do encontro, nenhuma pesquisa de campo similar à proposta deste estudo foi apresentada. 
Enquanto o 'ver teatro' consiste no fazer experiência dos produtos e, portanto, da espetacularidade, dimensão visível do fazer teatral, o 'ver-fazer teatro' consiste no fazer experiência dos processos, isto é, da performatividade, dimensão geralmente invisível do fato teatral, cuja atenção é voltada a quem age e não a quem assiste. (MARINIS 2010 p. 99)

A articulação entre os pensamentos de Iser e de Marinis aponta para o fato de que o estudo isolado das partes da relação criação-recepção requer necessariamente o acompanhamento do processo de criação como modo de adquirir algum conhecimento da obra, antes que ela se torne evento atualizado pelo espectador.

Quem escreve a história do teatro frequentemente se confronta com testemunhos sobreviventes não tendo suficiente experiência dos processos artesanais do espetáculo. Desse modo corre o risco de não fazer história e de, em vez disso, acumular deformações da memória. (BARBA 1994 p. 26)

Note-se que o conhecimento do potencial de efeitos torna-se ainda mais relevante quando o estudo recai sobre criações que provocam percepções muito diversas, por vezes, até opostas.

Tais premissas levaram a pesquisadora ao acompanhamento intensivo, a partir do dia 22 de setembro de 2010, do processo de criação do espetáculo Bom Retiro, 958 metros. O procedimento adotado, observação participativa, recomenda que se tenha o cuidado de tomar notas, realizar registros sonoros e/ou visuais. Porém a caótica e instável mobilidade entre desejo e forma que se instaura nas primeiras etapas de criação artística exige do pesquisador alguma objetividade de observação. Buscou-se então apoio nas ferramentas da Crítica Genética, ciência que reconhece tal instabilidade e estuda a criação artística por meio da análise do ato criador registrado em manuscritos, diários e esboços.

A grande contribuição dessa ciência para o pesquisador de processos de criação teatrais está no procedimento adotado, que é o de trabalhar a partir da materialidade dos elementos moldados durante $o$ ato criador e centrar sua análise no embate entre ideias e forma, entre o planejamento conceitual do artista e a moldagem dos materiais. É relevante nesse campo o trabalho da pesquisadora brasileira Cecilia Almeida Salles que, em suas teorizações, mostra que a matéria resiste e interfere na criação. Uma forma surgida até mesmo ao acaso, no embate do artista com seus meios, pode se impor abrindo nova vertente em um trajeto que por si só já se configura labiríntico. "A rota é temporariamente mudada, o artista acolhe o acaso e a obra em progresso incorpora os desvios" (SALLES 1998 p.36). 
Tal linha de raciocínio é ainda mais relevante quando essa ciência salta da literatura - origem tanto da Estética da Recepção quanto da Crítica Genética - para a arte teatral, cuja materialidade inclui os corpos vivos dos atores, atravessados por afetos e emoções, matéria que permanece instável mesmo quando a obra atinge a etapa da recepção. No caso do Teatro da Vertigem há que se levar em conta ainda a ação do espaço sobre a moldagem da obra. No espetáculo em estudo, que tem o bairro do Bom Retiro como tema e território, as primeiras moldagens do material pesquisado pelo grupo se dão por meio de workshops, cenas criadas a partir de estímulos propostos pela equipe de direção, realizados em ruas, lojas e corredores de shoppings, entre outros locais do bairro. As negociações para tais ocupações são constantes e nem sempre pacíficas, e as resistências ora são quebradas, ora são incontornáveis, provocando modulações e/ou alterações no trabalho.

Uma possível limitação da crítica genética reside no procedimento retrospectivo. "O processo criador é repleto de decisões que não deixam rastros" (SALLES 2008 p. 114). Tal constatação reforça a importância de acompanhar o processo de criação no momento mesmo em que se dá, e não a partir de vestígios, mas não invalida a utilidade dos procedimentos analíticos dessa ciência.

A estreia em maio de 2012 marcou o início da prospecção da recepção, porém a etapa anterior não foi interrompida, pois o espetáculo segue se alterando. A pesquisa está em pleno andamento, mas já é possível perceber que o campo de tensão que essa obra instaura nada tem de pacífico, pelo contrário, provoca diferentes estados de recepção e uma ampla gama de leituras, que serão objeto de análise na elaboração da tese. O que se propõe neste artigo é uma primeira aproximação na qual, sem ainda o rigor da tese, articula-se procedimentos de criação, potencial de efeitos e recepção.

\section{Puxando fios de outras tramas}

Desde sua gênese, em 1990, o Teatro da Vertigem vem forjando uma poética que coloca em fricção os elementos ficcionais moldados pelo grupo e os espaços 'reais' de representação. Ao criar encenações fora dos edifícios teatrais o grupo busca alterar por tensionamento o equilíbrio entre ficção e realidade, representação e presença, sempre instável na arte teatral. A escolha de ambientações carregadas de sentidos fortemente impressos no imaginário coletivo como uma igreja (Paraíso Perdido, 1992), um hospital (O Livro de Jó, 1995) e um presídio (Apocalipse 1.11, 2000), na criação da chamada Trilogia 
Bíblica, forjou a poética e a identidade do Teatro da Vertigem. Porém seria um equívoco confundir identidade poética com cristalização de procedimentos. Há movimento.

Nos espetáculos da trilogia bíblica os espaços eram circunscritos, havia paredes entre espaço da cena e cidade, fronteira que protegia e inevitavelmente atuava sobre o campo de tensão real/ficção. Uma análise aprofundada dos efeitos deste aspecto no campo obra/recepção fugiria ao objetivo desse artigo. No entanto, é importante ressaltar que o desejo de fender muros para o atravessamento do real sobre o espaço da cena já pode ser detectado na origem de Apocalipse 1.11, quando o grupo buscou atuar no presídio do Carandiru ainda em funcionamento, o que lhe foi negado, e ainda quando atuou em hospitais e presídios em funcionamento durante as temporadas de O Livro de Jó e Apocalipse 1.11. Em BR3 (2006), encenado sobre as margens e leito do rio Tietê, o espectador está dentro de um barco em movimento e seu olhar vaza para o movimento cotidiano dos carros que circulam pelas avenidas que margeiam o rio. O olhar do espectador não mais fica circunscrito ao espaço ‘ocupado' pela encenação, que se abre para a cidade, ampliando a instabilidade entre espaço real e referente ficcional.

Bom Retiro, 958 metros representa um salto nesse movimento. Desta vez a imbricação entre polos se estreita na mesma proporção em que se ampliam os espaços cênicos. A encenação processual ocupa os corredores e lojas de um shopping, atravessa ruas em trânsito por três quarteirões e ocupa ainda, na reta final do percurso, um teatro em ruínas, encerrando-se na calçada em frente ao teatro, criando assim uma nova zona de tensão no atrito dentro/fora, público/privado. A percepção do shopping como local protegido e das ruas como passagem de risco é recorrência na pesquisa de recepção. Altera-se ainda, significativamente, a criação ficcional. Se em BR3, por exemplo, uma comporta de represamento das águas do rio Tietê era transformada cenicamente na cidade de Brasília em obras na década de 1950 e ali começava a saga de uma família que percorria diferentes tempos e locais, agora, nesse Bom Retiro, 958 metros não há outros lugares e tempos ficcionais dentro de espaço real. As personagens - consumidores, costureiras, carregadores de mercadorias, cracômanos, mendigos, agentes sanitários, faxineira, noiva, terrorista poético, manequins, rádio são aparições do shopping, da rua e também do teatro abandonado, e em tempo presente. Não são personagens dramáticas, não estão interligadas por uma trama. São figuras tensionadas ficcionalmente pela articulação entre seus vínculos sociais e econômicos e o território pelo qual transitam. Quando falam - há muitas imagens 
sem palavras -, não dialogam, no sentido da interlocução que altera ou afeta pessoas interligadas emocionalmente, fazem discursos por meio dos quais se apresentam e problematizam questões relativas ao seu território de atuação. Desfilam diante do público, param, exibem corpos e palavras, vendem seus produtos ou sua força de trabalho. Nesse procedimento criativo, a produção de sentido tem de ser buscada não no eixo intracênico, num 'fundo' ficcional, mas no eixo extracênico, na articulação de elementos na sociabilidade que enreda figuras e espectadores. Vejamos uma dessas atualizações na recepção.

(...) Dedico parte considerável da minha vida, e quase toda a minha vida profissional, a refletir sobre os espaços urbanos, a exclusão, o medo da cidade, a perda de uma memória honesta travestida em uma nostalgia vazia de sentido. E ali na peça eu vi materializadas muitas de minhas reflexões e angústias, quando não esperava. (...) Então a peça não deixou de ser um reencontro comigo mesmo, com algumas crenças e lutas que encontraram ali várias pessoas compartilhando, quase uma experiência conjunta. (...) Mas se no espaço urbano eu encontrei na peça um compartilhar de lutas pessoais, dentro da galeria de compras é inevitável aquela sensação de autocrítica e vergonha ante o que era exposto. Somos partes de uma sociedade movida pelo consumo, portanto, também consumo. Evidentemente já tive paixões fulminantes por vitrines distantes de minha realidade econômica, já fiquei feliz com liquidações, já tive minhas próprias versões de vestidos vermelhos, ignorando completamente seus bastidores. Acho que o momento de pensar em outras experiências pessoais, ressoantes ali na crítica, e se achar instantaneamente ridículo ocorreu de uma maneira mais forte dentro da própria galeria, mas isso é a proposta da peça. (Psicólogo, 25 anos, doutorando em psicologia social)

A encenação escapa da chave realista por meio de diversos recursos de estranhamento. Por exemplo, no deslocamento de costureiras trabalhando expostas em vitrines, que inverte a relação produção/produto. Outra qualidade de inversão ocorre quando o público passa a estar na 'vitrine' e o movimento da rua se transforma em 'cena' no saguão do teatro. Há ainda outros procedimentos de estranhamento no uso da linguagem do musical e na humanização de objetos como vestido, manequins, rádio.

Tal linguagem estranhada é ponto de chegada de um longo e labiríntico processo de criação. Porém, ressalte-se, tema e território surgem imbricados desde a gênese desse espetáculo. Em uma reunião realizada pelo grupo no dia 26 de outubro de 2008, gravada pelo cineasta Evaldo Mocarzel, que tem prestado grande contribuição aos pesquisadores ao realizar documentários de processos de criação, os integrantes discutem possíveis temas para uma encenação de grande envergadura em horizonte futuro ${ }^{3}$."Relações de trabalho, exploração financeira, valor da desvalorização, capita-

\footnotetext{
${ }^{3}$ Essa reunião ocorre entre dois trabalhos de 'menor porte' do grupo. Entre os dias 12 a 15 de abril de 2008, em parceria com o grupo chileno Lot e o mineiro Zikizira, o Teatro da Vertigem realiza uma intervenção numa
} 
lismo e desterritorialização são algumas das temáticas postas em pauta". A presença de imigrantes latino-americanos no bairro do Bom Retiro e as denúncias de 'trabalho escravo' nos noticiários, também vem à tona. $\mathrm{O}$ encontro dura pouco mais de uma hora, é realizado na sede do grupo, e tem entre seus participantes o diretor Antônio Araújo, o iluminador Guilherme Bonfanti, a diretora de cena Eliane Monteiro e os atores Sérgio Siviero, Luciana Schwinden e Roberto Audio.

Ainda que não tenha sido conclusiva - várias propostas são discutidas, e a convergência que levaria a uma decisão só viria cerca de um ano depois -, importa ressaltar que já nessa reunião o bairro surge como possível espaço de atuação em estreita articulação com a temática econômica e social. Tema e território surgem de forma indissociável desde o ponto de partida e assim atravessarão, amalgamados, todo o processo de criação até a forma que passa a ser compartilhada pelo público. "O espetáculo atravessa a própria carne de seu tema, viaja através do tecido da cidade, do bairro. A recíproca é verdadeira,' observa a jornalista e dramaturga Marta Goes, ouvida na etapa da pesquisa de recepção ao espetáculo, quatro anos depois daquela reunião.

No modo de criação do Teatro da Vertigem, a etapa seguinte da decisão por um tema é a de pesquisa teórica. Vale destacar algumas informações, colhidas e agrupadas das falas dos participantes do primeiro ciclo de palestras promovido pelo grupo ${ }^{4}$, pois será matéria trabalhada nos workshops.

Com área de 10 mil metros quadrados - atualmente cerca de 400 quarteirões e 25 mil habitantes - de terras desvalorizadas por se situarem numa região de várzea cortada por rios e marcada por constantes inundações, o local é, desde sua origem, habitado por pessoas de baixa renda. Estrutura-se como bairro operário a partir de 1890 ao receber imigrantes destinados ao trabalho urbano. A inauguração das estações da Luz (1867) e Júlio Prestes (1872) intensifica a vocação de lugar de passagem para imigrantes de primeira geração. A canalização dos rios não valoriza a área, pois se dá quando a via férrea perde importância para a malha viária.

passagem de pedestres subterrânea do centro da cidade - $A$ Última Palavra É a Penúltima. No dia 4 de fevereiro de 2010 entra em cartaz Kastelo, montagem dirigida por Eliana Monteiro, cujo tema eram relações de trabalho e na qual os atores do Teatro da Vertigem atuavam pendurados em cordas ou sobre andaimes do lado de fora da fachada de vidro de um prédio da Avenida Paulista. São frutos de processos de criação de curta duração, alguns meses, se comparados aos da trilogia bíblica, BR3 e Bom Retiro, 958 metros, que tomaram em média dois anos.

${ }^{4}$ Intitulado Bom Retiro: Sociabilidade Urbana e Segregação, esse primeiro ciclo de encontros transcorreu entre os dias 3 e 24 de maio de 2010, na sede do Teatro da Vertigem. Os palestrantes: a psicóloga Vera Telles, a arquiteta e urbanista Raquel Rolnik, o antropólogo Heitor Frúgoli Jr., a urbanista Sarah Feldman, a psicóloga Sylvia Duarte Dantas e o sociólogo Oswaldo Truzzi. 
Na década de 1920 chegam judeus e italianos, além de gregos e armênios, entre outros imigrantes europeus, e também nordestinos. Ainda que não se configurem maioria, os judeus se dedicam ao comércio de roupas, primeiro como mascates, depois abrindo pequenos negócios e acabam imprimindo a identidade econômica e arquitetônica do bairro - lojas no térreo, confecção e moradia na parte superior de sobrados. A natureza dessa atividade, que exige pouca qualificação da mão de obra, torna-a flexível às diversas crises e à transferência entre etnias. Com formação universitária, grande parcela dos herdeiros judeus passa os pontos para a nova leva de migrantes coreanos, que chega na década de 1960. Trinta anos depois, intensifica-se a migração de bolivianos, peruanos e paraguaios, que passam a trabalhar nas confecções.

O dinamismo econômico do bairro, fundado em mão de obra de baixa qualificação e forte cultura do trabalho - característica de imigrantes de primeira geração - faz dele um território modelo para problematizar uma atmosfera de otimismo detectada em diferentes setores da sociedade e difundida pelos meios de comunicação, provocada pela crescente inserção no mercado consumidor das classes C, D e, sobretudo no segundo mandato do governo Lula. Se ganhos são inequívocos, há custos. São questões, entre outras, debatidas mais tarde nos ensaios e presentes nas anotações da pesquisadora já em campo.

Outro aspecto fundamental reside no fato de o bairro ser exemplar de uma importante mudança de uso do espaço público que não se restringe ao Bom Retiro. Das quermesses ao futebol de várzea passando pelas brincadeiras infantis nas ruas - muitos eram as oportunidades de socialização que amenizavam preconceitos e segregações. Os imigrantes das últimas levas chegam à cidade do carro e do lazer em ambiente privado, num tempo de relações mediadas basicamente pela economia de mercado.

\section{Costurando com a matéria viva dos corpos}

Pesquisas teóricas informam a frio. É no corpo de seu tema que o grupo vai trabalhar desde os primeiros passos da etapa prático-teórica. Assim, é numa deriva noturna pelas ruas desertas do bairro que tem início o trabalho da pesquisadora, em setembro de 2010. Nessa noite já estavam integrados ao grupo o escritor Joca Terron, convidado para criar o texto em processo colaborativo, o dramaturgista Antonio Duran e o assistente de direção Maurício Perussi.

Vários homens e mulheres agachados no asfalto, removendo retalhos de tecidos espalhados por toda a rua e extraídos de dezenas de sacos de lixos sob a luz fraca 
dos postes de iluminação pública, é uma imagem que afeta os participantes já naquela primeira noite. O dinamismo econômico tocado por imigrantes se revela e ao mesmo tempo se oculta em seus vestígios. A quantidade imensa de retalhos é índice da dimensão da produção diária enquanto catadores de restos ínfimos revelam o custo humano de um sistema que precisa de sobras - pessoas reduzidas ao contorno mínimo da sobrevivência - para que lhes caibam os adjetivos positivos de 'dinâmico e flexível'. Os consumidores de crack que cercam Audio e, em outro ponto, Terron, é outra experiência colhida nessa noite.

Em janeiro de 2011 tem início a fase dos workshops que nas minhas notas foram chamadas de pesquisa-carne, pois é o período em que todas as informações colhidas nas etapas anteriores - pesquisa teórica e reconhecimento de espaço - têm de passar pelo corpo dos atores, ganhar materialidade cênica.

O bairro já é presença atuante sobre o imaginário do grupo antes mesmo do início dessa fase de primeira moldagem de materiais a partir do corpo. A carga histórica de alguns locais visitados nesta fase de reconhecimento afeta os participantes e deixará vestígios no trabalho mesmo se esses locais não são atravessados no percurso do espetáculo. Por exemplo, do Desinfectório Central, instituição criada em 1893 para combate a epidemias, atual Museu de Saúde Emílio Ribas, sairão as figuras dos agentes sanitários que perseguem cracômanos, ligando a política higienista do século XIX às práticas similares do século XXI.

Seria um equívoco abordar o processo de criação apenas no sentido do que afeta o grupo. Há um intenso trabalho ativo por meio dos workshops. Cada elemento colhido da pesquisa teórica ou dado de observação é reconfigurado em sala de ensaio em sucessivas e diferentes moldagens que, num movimento nada retilíneo, se articulam até a criação final.

Uma visão simplificadora do gesto criador mostra um percurso que tem sua origem num insight e se concretiza ao longo do processo criativo. Essa perspectiva contém uma linearidade que incomoda aqueles que convivem com a não-linearidade e a simultaneidade desse fenômeno. Seria um modo limitador de olhar para esse trajeto (SALLES 2008 p.76)

O acompanhamento do processo de criação revela a intrincada rede autoral e polifônica que se estabelece no processo colaborativo. Escolho uma, entre tantas cenas possíveis, para fazer uma aproximação do campo de tensão proposto, ou seja, uma abordagem que articule processo de criação, um fragmento do potencial de efeitos e, já como evento, sua atualização na recepção. 
No dia 16 de fevereiro de 2011, os integrantes do grupo visitam uma oficina de costura ilegal boliviana. Cinco dias depois, a atriz Mawuse Tulani propõe uma cena para ser executada por duas outras atrizes e um ator - é dela a ideia, mas a atriz não se sente capaz de realizá-la. A cena é feita na Oficina Cultural Oswald de Andrade, numa sala usada como espaço de criação e na qual o grupo guardava material nos ensaios.

A cena realizada: duas costureiras sentadas em cadeiras, em pontos opostos da sala (Raquel Morales e Laetitia Augustin-Viguier), fazem com as mãos movimento de costura. Atrás delas, peças de roupas amontoadas vão sendo sacadas uma a uma e jogadas à frente, como se elas as tivessem costurado. Roberto Audio assume o papel de gerente da oficina e passa a estimular a competição entre a dupla, que produz em ritmo cada vez mais acelerado. Quando as peças disponíveis acabam, elas tiram a roupa do corpo e as lançam junto às produzidas, mas a cobrança continua. Nuas, passam a disputar a partir do próprio corpo, se atracam em briga violenta. Ao fim, beijam-se na boca, e a impressão da pesquisadora é a de que esse gesto carinhoso surge após o que elas consideravam fim da cena, da necessidade das atrizes de limpar a relação da violência que também as afetou.

Naquela tarde, dentro da sala de ensaios, a cena dos corpos em disputa é impactante. A pesquisadora faz a seguinte anotação: "nossa, que força tem a presença corporal; a cena me moveu fortemente, fiquei emocionada". O papel dos participantes do processo como primeiros receptores é algo a ser levado em conta no estudo.

$\mathrm{Na}$ primeira versão do texto, na etapa seguinte, essa cena reaparece alterada pelo escritor Terron, que acompanhara diariamente a primeira fase dos workshops, que teve duração de três meses. E reaparece com a indicação de que seja realizada no shopping, já pensado como um dos possíveis espaços de atuação. As duas mulheres agora estão sós e diante de uma banca de roupas em liquidação dessas de lojas populares. Tentam escolher muito rapidamente as peças que mais lhes interessam e por garantia vestem umas sobre as outras. Subitamente, elas se olham e percebem que estão vestidas iguais. Inicia-se a disputa corporal até a nudez de ambas, quando então se beijam e um fio sai de suas bocas. Terron foi buscar esse 'fio' em outro workshop da etapa anterior, realizado a partir de uma das propostas do diretor Antônio Araújo aos atores: criar micronarrativas de desfile. Sob tal estímulo, a atriz Luciana Schwinden criou o movimento de duas manequins (ela e Laetitia Augustin-Viguier) que se beijam ao cruzarem-se numa passarela e desse ato saía de suas bocas o fio. 
Na primeira versão de Terron, a faxineira cortava o fio com uma tesoura encerrando a cena. Algumas versões mais tarde, essa personagem seria substituída pela costureira. Interessante ressaltar que, desde essa primeira versão, o autor retira as palavras de origem. Seria impossível para um observador que não tivesse acompanhado o processo de criação detectar a presença do escritor na malha autoral dessa cena. $O$ mesmo pode-se dizer da trilha musical que acompanha a cena, a abertura da ópera La Gazza Ladra, de Rossini, proposta por Miguel Caldas durante os ensaios. Ele acompanhara os workshops experimentando sonoridades e seu trabalho inspirou o som móvel do espetáculo. É Caldas quem controla toda a parafernália de microfones e executa a trilha num carrinho itinerante que remete às carroças puxadas por catadores de papelão do bairro.

Em março de 2012, o diretor Antônio Araújo desloca essa disputa para um movimentado cruzamento entre duas ruas no bairro do Bom Retiro. Já não há mais banca de liquidação, apenas duas mulheres que se encontram ao acaso, vestidas iguais. No meio dos ensaios, o diretor agrega um coro de atores que estimula a disputa aos gritos e risos envolvendo-as com um ringue feito de tiras de tecido. Por questão de logística, ocorre a substituição de Raquel Morales por Bia Bouisson, uma das atrizes do coro formado por nove integrantes que se incorporaram ao trabalho em fevereiro de 2012. Por fim, a coreógrafa Renata Mello criou com as atrizes o desenho final da luta.

Depois de tantas alterações, os vestígios da vertente trabalho/produção pareciam apagados. Por isso foi surpreendente detectá-los na recepção já na etapa dos ensaios abertos:

\begin{abstract}
A cena mais marcante para mim foi a briga das mulheres, porque é assim mesmo, quando duas pessoas com a mesma capacitação concorrem a uma vaga, elas tem de se matar para consegui-la (funcionário público, formação em arquitetura, 30 anos).
\end{abstract}

Não seria uma leitura isolada, outras semelhantes viriam. Por outro lado, ao longo da pesquisa, alguns espectadores criticam nessa cena o que veem como exploração do corpo feminino no (mau) sentido apelativo, como se tivesse sido criada para atrair o olhar masculino.

Compreendo o contexto, mas não entendo a exploração desse fetiche. A luta das funcionárias de uma loja na rua, recurso bastante eficiente para exploração da nudez e do fetiche masculino (duas mulheres se beijando). (filósofa)

A percepção de que essa visão negativa da nudez vinha se tornando recorrente na recepção é repassada pela pesquisadora ao diretor. Antônio Araújo faz nova alteração: 
prolonga a cena que se encerrava no momento em que o fio era cortado, quando se acendia imediatamente a projeção luminosa sobre a figura da noiva (Raquel Morales). Agora, após o corte do fio, ainda sob o olhar do público, elas caminham devagar pelas ruas, no meio dos carros. A alteração ressoou na recepção:

A memória do meretrício do bairro, representado pela briga das duas mulheres, e citada pela 'noiva perdida', merecia continuidade. (arquiteto urbanista e professor da FAU/USP).

O espectador articulou essa cena a outra do percurso, que faz referência à zona de prostituição que marcou a história do bairro em meados do século passado. Aqui o vetor produção/trabalho reaparece reconfigurado e, assim, altera o potencial de efeitos.

O traçado dessa única cena serve para uma aproximação do grau de complexidade desse processo de criação e sua intrincada malha autoral, que passa por corpos e afetos, e tem seus integrantes como primeiros receptores.

Seria possível realizar diferentes traçados do processo, puxando fios de outros momentos da criação. Porém, o âmbito desse artigo pede agora um salto para um olhar necessário sobre vetores e linhas de força.

\section{Uma linha se destaca na tessitura}

Questões de sociabilidade e segregação - não por acaso título do primeiro seminário realizado pelo grupo - perpassam todo o processo de criação desde sua origem. Porém, após os workshops, desde a primeira versão do texto, o grupo detecta o desenho de uma importante linha força que surge no processo de criação e se articula à busca inicial: a fantasmagoria.

O capitalismo contemporâneo não produz mais alegorias, mas fantasmagorias - fantasmas-ágora - fantasmas ocupam a Ágora, a política confunde-se com a economia, nada mais escapando às determinações do mercado. (MATTOS 2008 p.162).

Pode-se definir o fantasma como um ser errante, descolado de seu corpo, uma presença sem materialidade, que vaga prisioneiro de uma obsessão que nada mais tem a ver com desejos da carne e dos afetos.

Esse é o 'estado' da consumidora compulsiva em sua busca obcecada por um vestido vermelho, uma das figuras presentes no espetáculo em cartaz, interpretada por Luciana Schwinden. Vejamos algumas de suas palavras. "Eu preciso voltar para casa, um banho não seria nada mal, mas falta pouco, falta aquele vestido vermelho. Quanto tempo se passou? Acho que faz uma semana que não volto para casa; acho 
que já passei por essa rua... Será que eles mudaram o sentido das ruas? Acho que faz mil dias que estou aqui." Trata-se de um ser sem referências de tempo e espaço, que não evolui, anda em círculos prisioneira de um eterno presente.

É também o estado da guia interpretada por Laetitia Augustin-Viguier, cuja expressão permanente é de total alheamento, sempre com uma TV nas mãos. Curiosamente essa personagem foi sugerida, em sua primeira moldagem, pelo escritor Terron já como personagem muda e fantasmática, o que reforça como é difusa a questão da autoria na tessitura coletiva e heterárquica do Teatro da Vertigem, difícil de ser detectada, sobretudo se analisada apenas do ponto de vista da expectação.

Outro elemento que reforça a atmosfera fantasmagórica tem origem num dado de observação. A presença constante do rádio nas oficinas ilegais de costura faz desse veículo um elemento exaustivamente explorado em diferentes aspectos nos workshops. Muitas foram as proposições até que tenha ganhado a forma estranhada presente no espetáculo: a Rádio Infinita, personificada no corpo e na voz da atriz Sofia Boito, que tem o rosto coberto por uma máscara metalizada com dois pontos luminosos no lugar dos olhos. O objetivo de seu 'show insone', patrocinado por um antidepressivo, é penetrar nos sonhos dos ouvintes embalando dessa forma o ritmo da produção e das compras. Estabelece um diálogo de 'surdos' com a costureira boliviana quando esta fala de seu sonho de um possível rompimento da cadeia produção/consumo que aprisiona ambas na madrugada insone. Não por acaso a rádio será alvo dos ataques do terrorista poético (Roberto Audio) que, na articulação de sentidos proposta pelo espetáculo, é o único em busca de desestabilização em vez de inserção, o único que age para quebrar a inércia que aprisiona a todos no mesmo movimento circular.

De forma mais ou menos evidente, a fantasmagoria perpassa todas as cenas atravessadas pela relação humano-coisificado/coisa-humanizada. Não há espaço para encontros de corpos vivos na Ágora contemporânea. Só entrecruzamentos de figuras com seus discursos de compra-e-venda, por meio dos quais exibem capacidades de produção ou de sedução.

A produção de sentido desejada, a problematização de uma sociabilidade, chega como potencial de efeitos nessa criação, e é atualizada na atividade receptiva como pode ser detectado nos depoimentos de dois espectadores de diferentes horizontes de expectativas:

Entrar num shopping fechado, percorrer ruas e, depois entrar no teatro foi uma experiência de me aproximar daquilo que a gente está vendo, mas que 
poucas vezes parece que percebemos. A rua deixa de ser só um caminho para chegar a algum lugar, e passa a ser um lugar, onde se vivem várias coisas. (...) É o impacto de se deparar com a nossa condição real, de quem nada ouve e nada vê. (Rafaela, estudante de Psicologia, 22 anos).

Nós também somos os consumidores. Sentados nos degraus da sinagoga (ele se refere à escadaria do saguão do Teatro da Associação Israelita Brasileira (TAIB) de onde o público pode observar, durante uma cena, o movimento das ruas através das portas de vidro), no templo dos argentários e dinheiristas, segundo o preconceito que acusa os judeus, nós também somos transformados em manequins-bonecos para quem passa e, pagando pelo espetáculo, não só nos constituímos como consumidores de cultura, como também, só aí, pagando, mediando nossas relações pelo dinheiro, repito, só aí é que assistimos à cidade, vemos os tipos que passam pela porta envidraçada do local, visitamos ruas às quais normalmente não vamos. (Sérgio, jornalista, formado em História)

Note-se que muitos espectadores se incorporam ao espetáculo no seu percurso, o que quebra em parte a mediação econômica obra/receptor.

Outro ponto que gostei bastante foi do fato de não limitar quem está sem ingresso. Tá passando pela rua e quer acompanhar a peça? Acompanhe! (embora eu entenda que foge do controle e da capacidade de segurança) (Luana, 26 anos, publicitária).

\section{Arrematando a costura}

O exposto até aqui representa uma pequena parcela do que já foi investigado. E, como dito, trata-se de pesquisa em andamento. O que segue, portanto, são alguns arremates embrionários, sobre uma vasta matéria que pede análise pormenorizada.

A percepção de risco no desolamento das ruas desertas que se articula à consciência do próprio corpo em trânsito por espaços aonde não se vai ou, quando ocorre, se dá em condição utilitária e funcional, semelhante à da consumidora, com a cegueira do objetivo. Protegido no espaço fechado do teatro na reta final do percurso, o espectador é mais uma vez lançado à rua, expulso como um cracômano, ao som de sirenes, luzes e jatos d'água pelos 'fiscais sanitários'.

Quando eu percebi no início da peça que estava havendo uma crítica ao higienismo absurdo que ocorreu na cracolândia eu me emocionei, mas quando eu me vi correndo no teatro abandonado eu chorei, fiquei muito tocada, muito. (...) fiquei muito extasiada com o posicionamento político desta peça! (41 anos, psicanalista)

Embora o ponto de encerramento do espetáculo esteja a passos do ponto de partida, é comum ouvir espectadores se perguntando: "Onde estamos? Não vão nos levar de volta".

Como ação de intervenção urbana, Bom Retiro, 958 metros interfere e desestabiliza o uso funcional/mercantil da metrópole, ultrapassando o território no qual atua, 
pois tendo o bairro como referencial, a temática o ultrapassa. A encenação tem ainda caráter de site specific, se aceita a definição de obra cujo sentido brota da articulação entre a criação do artista e o lugar de exposição. Porém, intervenção urbana e site specific talvez sejam categorias insuficientes para definir essa encenação porosa e potente o bastante para atravessar e se deixar atravessar pela materialidade saturada da metrópole urbana sem ser arrastada pelos seus fluxos.

Muitos são os teóricos que abordam a teatralidade contemporânea sob o aspecto das contaminações vindas de experimentações do campo das artes plásticas - performances, instalações, intervenções. Desse ponto de vista, o caráter produtivo e não representativo, ou seja, o predomínio da presença e da materialidade sobre a narrativa e fábula, definidos como modos de fazer desse campo artístico, torna-se fonte de influência para a atividade teatral. Todos o que se aproximam de alguma forma dos estudos da cena contemporânea já entraram em contato com as muitas variações sobre o tema a partir de termos como "teatralidades híbridas, fronteiriças, liminares, pós-dramáticas", cunhados ou analisados por autores (PAVIS, FÉRAL, LEHMANN,) cuja enumeração seria extensa. Evidentemente não se trata de um pensamento em bloco. Pelo contrário, trata-se de um debate pleno de nuances e fricções de grande contribuição aos analistas e criadores das teatralidades contemporâneas. Porém o caráter convivial é aspecto importante a ser considerado nessa criação do Teatro da Vertigem.

Qualquer tentativa de documentar ou estudar contaminações na arte desvinculadas de sua relação com o entorno reduziria a sua complexidade e anularia uma parte do espesso tecido arte/sociedade arte/realidade (DIÉGUEZ 2011 p.40)

O teórico argentino Jorge Dubatti está entre os pesquisadores que propõem uma abordagem ontológica do teatro capaz de detectar nessa arte o seu núcleo singular, sem negar intersecções. Em palestra realizada em setembro de 2012, no Brasil, no I Colóquio Internacional da Recepção, esse pesquisador observou que no Dicionário de Teatro de Patrice Pavis não há um verbete que trate de teatro sem extensões - teatro épico, teatro invisível, etc. - e falou da busca por uma ciência do teatro, arte cuja especificidade, do seu ponto de vista, reside em fundar-se na tríade: convivência/poética/expectação.

Jorge Dubatti se propõe a redefinir a teatralidade a partir da identificação, descrição e análise das suas estruturas conviviais. Mais do que concentrarse estritamente num estudo de linguagem, a este investigador interessa o ato capaz de provocar a aparição do teatral: o encontro de presenças, reunião ou convívio sem o qual não teria lugar o acontecimento teatral (DIÉGUEZ 2011 p. 40). 
Não se pode compreender a poética do Teatro da Vertigem sem considerar seu modo de criação fundado em práticas coletivas e heterárquicas, em complexa rede de interações sociais. Poética que articula as vivências dos participantes à sociabilidade do seu entorno. Se, nesse estudo de caso, o aspecto convivial é relevante, tal importância se amplia por se tratar de prática comum, evidentemente com variantes, ao modo de criação de muitos outros grupos paulistanos.

\section{Referências bibliográficas}

ARAÚJO, Antonio. A Gênese do Vertigem. São Paulo: Perspectiva: Fapesp, 2011.

BARBA, Eugenio. A Canoa de Papel. Trad. Patricia Alves. São Paulo: Hucitec, 1994.

CABALLERO, lleana Diéguez. Cenários Liminares. Trad. Luis Alberto Alonso e Angela Reis. Uberlândia: EDFU, 2011.

DUBATTI, Jorge. Teatro, Ciências da Arte e Epistemologia: Uma Introdução. Conferência no I Colóquio Internacional da Recepção: Abordagens sobre a Relação Obra de Arte/Espectador. Salvador: PPGAC/UFBA. Dia 5 de setembro de 2012.

FÉRAL, Josette. Por uma Prática da Performatividade. Revista Sala Preta, nº 8. São Paulo: PPG/ECA-USP, 2008, p. 197-210.

JAUSS, Hans Robert. Pour une Esthétique de la Réception. Tradução alemão/francês. Claude Maillard. Paris: Gallimard, 1974.

LEHAMANN, Hans-Thies. O Teatro Pós-Dramático. Trad. Pedro Süssekind. São Paulo: Cosac Naify, 2006.

MARINIS, Marco De. Nova Teatralogia e Perfomance Studies: Questões para um Diálogo. Revista Repertório n ${ }^{\circ}$ 13. Salvador, PPGAC-UFBA, 2010. p. 95-103.

MATOS, Olgária. Walter Benjamim: Pólis Grega, Metrópoles Modernas. In: Walter Benjamim: Formas de Percepção, Estética na Modernidade. Organizadores: Evaldo Souza Couto e Carla Milani Damião. Salvador: Quarteto, 2008. p. 157-177.

PAVIS, Patrice. Dicionário de Teatro. Trad. J. Guinsburg e Maria Lúcia Pereira. São Paulo: Perspectiva, 1999.

SALLES, Cecilia Almeida. Redes da Criação - Construção da Obra de Arte. Vinhedo: Horizonte, 2006.

Crítica Genética: Fundamentos dos Estudos Genéticos sobre o Processo de Criação Artística. São Paulo: Educ, 2008.

Gesto Inacabado. São Paulo: FAPESP: Annablume, 2009. Arquivos de Criação. Vinhedo: Horizonte, 2010. 